\title{
KINETIC AND THERMODYNAMIC STUDIES OF METHYL ORANGE ADSORPTION ONTO MESOPOROUS CARBON COATED MONOLITH (SYNTHESIZED BY SURFACTANT)
}

\author{
Zamratul, M.I.M \& Thomas, S.Y. Choong \\ Department of Chemical and Environmental Engineering \\ Faculty of Engineering, Universiti Putra Malaysia, 43400 Serdang, Selangor Darul Ehsan, Malaysia \\ Corresponding author: zamratul.maisarah@yahoo.com
}

\begin{abstract}
Ceramic monolith was chemically modified for the purpose of developing an adsorbent known as carbon coated monolith (CCM). The carbon coated monolith was characterized by using Brunauer-Emmet and Teller (BET) and Barret-Joyner-Halenda (BJH), point zero charge (pHpzc) and surface chemistry. The kinetics adsorption of methyl orange followed a pseudo-second order kinetic model. Thermodynamic parameters such as enthalpy change $\left(\Delta \mathrm{H}^{\circ}\right)$, free energy change $\left(\Delta \mathrm{S}^{\circ}\right)$ and entropy change $\left(\Delta \mathrm{G}^{\circ}\right)$ were calculated from the slope and intercept of the linear plot of $\ln \mathrm{K}_{\mathrm{L}}$ against $1 / \mathrm{T}$. Analysis of adsorption results obtained at $\mathrm{T}=(298 \mathrm{~K}, 303 \mathrm{~K}$ and $313 \mathrm{~K})$ showed that the adsorption process of methyl orange was found to be endothermic and spontaneous.

ABSTRAK Monolit seramik telah dimodifikasi secara kimia untuk digunakan sebagai penjerap yang dikenali sebagai monolit mesopori bersalut karbon. Monolit mesopori bersalut karbon telah diujikaji melalui analisa Brunauer-Emmet and Teller (BET) dan Barret-Joyner-Halenda (BJH), titik caj sifar (pHpzc) dan kimia permukaan. Data kinetik bagi jerapan menunjukkkan bahawa jerapan mematuhi model kadar tertib pseudo-kedua. Ujikaji parameter termodinamik seperti entalpi $\Delta \mathrm{H}^{\circ}$, perubahan entropi $\Delta \mathrm{S}^{\circ}$ dan perubahan tenaga bebas $\Delta \mathrm{G}^{\circ}$ telah diukur dari kecerunan dan pintasan yang diperolehi dari plot $\ln \mathrm{K}_{\mathrm{L}}$ melawan 1/T. Analisa menunjukkan proses penjerapan adalah bersifat endotermik dan spontan
\end{abstract}

(Keywords: Adsorption, methyl orange, mesoporous monolith, kinetic, thermodynamic. )

\section{INTRODUCTION}

Textile industry is a growing industry in Malaysia which contributes about $22 \%$ of the total volume of industrial wastewater generated in the country [1]. For instance, a relatively recent survey of the Malaysian textile industry has revealed that the volume of wastewater generated by dyeing and finishing operations ranged from 73 to $167 \mathrm{~m}^{3}$ per ton of product [2]. The properties of dye compounds which are synthetic organic compounds with complex molecular structures and large molecular weights cause treatment difficulties of dye wastewater [3]. One of the dyes present in the effluent is methyl orange. Methyl orange is a yelloworange, water-soluble azo dye, which is widely used in the textile, food, pharmaceutical, printing, paper manufacturing and also in research laboratories [4].

Activated carbon has been generally used to remove composite reactive dye from dyeing unit effluent [5]. Adsorption on activated carbon is the most known technology used in removal of dyes [6], phenols [7]; [8], pesticides and other hazardous chemicals [9]. Due to their surface area and porous structure, activated carbons have the advantage of exhibiting a high adsorption capacity for colour. Although, activated carbon is preferred as adsorbent for the removal of dye, the efficiency of adsorption is determined based on the molecular size of the dye. Based on the research done by Walker and Weatherly [10], only $14 \%$ of the pores over the surface of activated carbon are being occupied by the acidic dye molecules via adsorption. The slow solute diffusion in the activated carbon results in low adsorption. The problems encountered above may be overcome by the use of carbon monoliths.

Considering the shortcoming, a ceramic monolith will be modified into mesoporous activated carbon. The cordierite monolith is impregnate with furfuryl alcohol as carbon source and F127 surfactant as pore forming agent. Based on previous studies by [11], surfactant F127 can be used to modify the 
surface of the mesoporous carbon and results showed that F127 surfactant was effective to improve the dispersion capacity of nanosized silica particles when the proper amount added. Pore volume and Brunauer-Emmet-Teller (BET) surface area of mesoporous carbon increased after the addition of F127 surfactant. The surfactant used in the present study also takes part in the formation of mesopores as well as blocking the micropores.

The aim of this study was to produce an adsorbent from ceramic monolith called carbon coated monolith. The carbon coated monolith was characterized by Brunauer-Emmet-Teller (BET) and Brunauer-Joyner-Halenda (BJH), point zero charge and surface chemistry method. Kinetics was evaluated using pseudo- first order and pseudo-second-order kinetic model. Thermodynamic parameters were studied to determine the adsorption process of methyl orange onto carbon coated monolith.

\section{MATERIAL AND METHODS}

\section{Preparation of Adsorbate}

Methyl Orange (C.I. 13025, $327.33 \mathrm{gmol}^{-1}$, $\mathrm{C}_{14} \mathrm{H}_{14} \mathrm{~N}_{3} \mathrm{NaO}_{3} \mathrm{~S}$,), an anionic dye was used as pollutant without further purification. Distilled water was used throughout the experiment and in the preparation of solution. A stock solution of methyl orange concentration $1000 \mathrm{mg} / \mathrm{L}$ was prepared by dissolving $1 \mathrm{~g}$ of powder dye in $1 \mathrm{~L}$ of distilled water. The range of methyl orange concentration used were $12.5 \mathrm{mg} / \mathrm{L}$ to $150 \mathrm{mg} / \mathrm{L}$.

\section{Preparation of Carbon Coated Monolith}

These ceramic monoliths were obtained from Beihai Huihuang Chemical Packing Co. Ltd, China.

The chemical compositions of the monolithic substrate used in this investigation are $\mathrm{SiO}_{2} 50.9$ $\pm 1 \%, \mathrm{Al}_{2} \mathrm{O}_{3} 35.2 \pm 1 \%, \mathrm{MgO} 13.9 \pm 0.5 \%$, and others $<1 \%$. The starting chemicals for the preparation of carbon coated monolith are furfuryl alcohol as carbon source, Pluronic F127 as pore forming agent, and nitric acid as polymerization catalyst.

\section{Preparation Procedures \\ Preparation of solution carbon from furfuryl alcohol and carbonization}

Furfuryl alcohol as precursor for carbon source was polymerized by using nitric acid as catalyst. F127 surfactant was added as pore forming agent and pyrrole as binder. The polymerization catalyst was added $(250 \mu \mathrm{L})$ stepwise to the mixture every 5 min. After catalyst addition, polymerization was slowly continued for an hour. Continous stirring and cooling were necessary to avoid thermal runaway reaction as the mixture was polymerized exothermally at ambient conditions. The polymerization temperature had to be maintained at 298 K. Prior to dip-coating, the monoliths were coated by immersion in polymerized solution for an hour. During this process, the fluid mixture was prepared by cooling in ice bath to slow down the rate of polymerization reaction and thereby maintaining constant viscosity. After withdrawal from the coating solution, excess coating solution was removed from monolith channel with pressurized air. The carbon coated monoliths were then heated for 24 hours at 100 ${ }^{\circ} \mathrm{C}$ for dip coating process [12] and were carbonized in a carbonizer at temperature $700{ }^{\circ} \mathrm{C}$ at heat rate of $3^{\circ} \mathrm{C} / \mathrm{min}$ with flowing $\mathrm{N}_{2}$ gas. The spontaneous carbonization of monolith liberates energy and hence this reaction is exothermic. Finally the activated carbon monolith was produced. The final weight of activated carbon was measured and recorded. It was then activated at $400{ }^{\circ} \mathrm{C}$ by passing argon gas with oxygen for 4 hours.

\section{Characterization of carbon coated monolith}

The nitrogen adsorption/desorption isotherm of CCM was measured using a Sorptomatic V1.03. The surface area and pores size distribution were obtained using the Brunauer-Emmet-Teller (BET) and Brunauer-Joyner-Halenda (BJH) calculations, respectively.

The $\mathrm{pH}$ of point zero charge of the methyl orange with the existence of carbon monolith was determined 1 gram of $\mathrm{KNO}_{3}$ was added into a $100 \mathrm{~mL}$ of distilled water. The tested $\mathrm{pH}$ was range between $\mathrm{pH} 2$ to $\mathrm{pH} 10$ which was adjusted using $\mathrm{HCl}(0.5 \mathrm{M})$ and $\mathrm{NaOH}(0.5 \mathrm{M})$. 1.5 gram of carbon monolith was added into each solution. These solutions were immediately sealed with parafilm and shaken at room temperature for 2 days. After 2 days, the $\mathrm{pH}$ of the solution was measured. Data obtained was recorded and analysed [13]. 
Amount of surface acidic and basic functional groups were determined using the Boehm titration method. The carbon samples were immersed into $50 \mathrm{~mL}$ solutions $\mathrm{HCl}(0.1 \mathrm{~N})$, $\mathrm{NaHCO}_{3}(0.1 \mathrm{~N}), \mathrm{Na}_{2} \mathrm{CO}_{3}(0.1 \mathrm{~N})$ and $\mathrm{NaOH}$ $(0.1 \mathrm{~N})$ and shaken for 48 hours. The suspension was then centrifuged at $5000 \mathrm{rpm}$ for 5 minutes. $10 \mathrm{~mL}$ of each solution was pipetted and the excess of base was titrated with $\mathrm{HCl}(0.1 \mathrm{~N})$. The number of surface basic sites was calculated from the amount of $\mathrm{HCl}$ that was reacted with the carbon [14]. The value of acidity sites can be calculated by using Equation 1 below.

Acidity $=$ Phenolic + Lactone + Carboxyl groups

\section{Batch Adsorption Studies}

For kinetic study, carbon coated monolith was used in contact with methyl orange for a period of time. 12.5 to $150 \mathrm{mg} / \mathrm{L}$ initial concentration of methyl orange with carbon monolith at its optimum $\mathrm{pH} 5$ was placed in the shaker. The shaker was operating at its ambient temperature and constant agitation speed of $220 \mathrm{rpm}$. For the first 20 minutes, a sample was taken at the length of 5 minutes. Next 30 minutes, a sample was taken at the interval of 10 minutes. This time interval will gradually increase until it reaches 4 hours. In order to obtain the concentration of solid adsorbate, the sample was analyzed by using UV-test. Finally, result was recorded. Same procedure was used for effect of temperature but with varies temperature $\left(20^{\circ} \mathrm{C}\right.$ to $40^{\circ} \mathrm{C}$ ). The amount of MO adsorbed at equilibrium, qe $(\mathrm{mg} / \mathrm{g})$, was calculated using Equation 2:

$$
q_{e}=\frac{\left(C_{e}-C_{0}\right) V}{m}
$$

\section{RESULTS AND DISCUSSION}

\section{Characterization of CCM}

The pore area and pore volume were estimated using $\mathrm{N}_{2}$ physisorption. The sample displays multi-modal pore size distribution in both the mesopore and micropore areas. The observed total pore area was $452.65 \mathrm{~m}^{2} / \mathrm{g}$ (mesopore area: $241.91 \mathrm{~m}^{2} / \mathrm{g}$ and micropore area: $210.74 \mathrm{~m}^{2} / \mathrm{g}$ ) and the total pore volume was $0.285 \mathrm{~cm}^{3} / \mathrm{g}$ (mesopore volume: $0.2778 \mathrm{~cm}^{3} / \mathrm{g}$ and micropore volume: $0.0067 \mathrm{~cm}^{3} / \mathrm{g}$ ). About $97 \%$ of the total pore volume fall is mesopore range indicating higher mesopore volume compared to micropore volume.

The point zero charge, $\mathrm{pH}_{\mathrm{pzc}}$ of $\mathrm{CCM}$ was measured to be 5.4. The $\mathrm{pH}_{\mathrm{pzc}}$ of an adsorbent is a very important characteristic that indicates the $\mathrm{pH}$ at which the adsorbent is neutral. The result shows that CCM was positively charged on its surface below $\mathrm{pH} 5.4$ and its favoured the adsorption of methyl orange. The Boehm titration experiments showed larger number of acidic sites over the surface of CCM. This indicates that the acidic functionality dominates over the surface of CCM.

As shown in Figure 1 (a), the shape of the isotherm is in Type IV and Type $\mathrm{V}$ according to adsorption isotherm by IUPAC. The type IV and $\mathrm{V}$ isotherm gives useful information on the mesopore structure through its hysteresis loop, that is, nonoverlapping of the adsorption and desorption branches These loops appear as a result of pressure differences required for adsorption and desorption that arise in mesoporous materials because of capillary condensation or evaporation. The results follow the hysteresis loop, H4 according to IUPAC, which indicate that the surface area of carbon coated monolith is slit-like pores. From Figure 1 (b) the result shows that the pore size is in mesopores range which is between $2 \mathrm{~nm}$ to 50 $\mathrm{nm}$. 
(a)

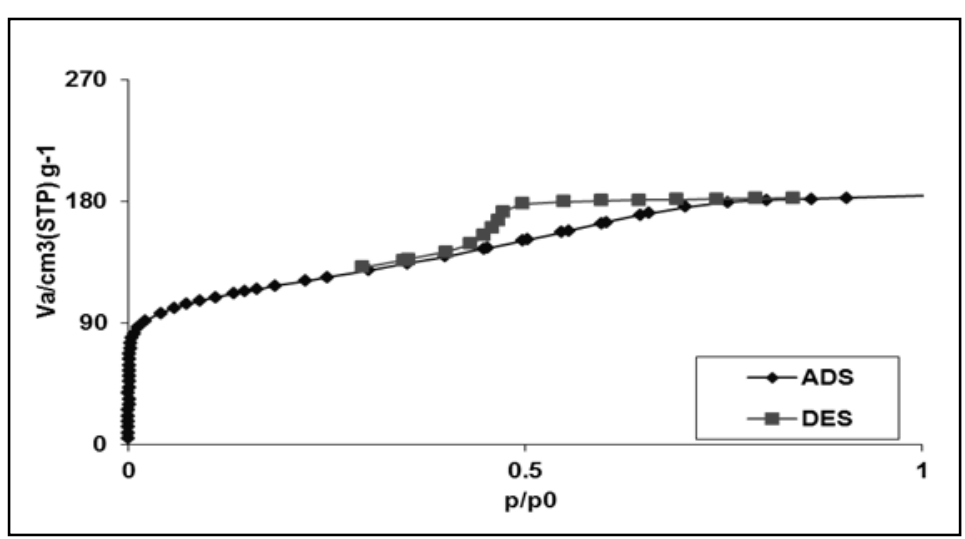

(b)

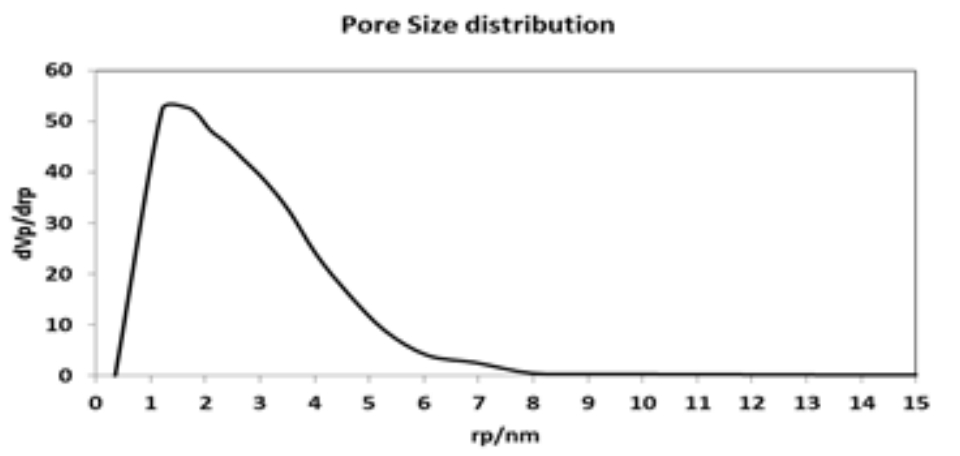

Figure 1. (a) $\mathrm{N}_{2}$ adsorption/desorption isotherms of carbon coated monolith (b) Pore size distribution of $\mathrm{CCM}$

\section{Adsorption Kinetics}

The adsorption mechanism of MO onto CCM was studied using pseudo-first-order and pseudo-second order kinetic equations. Lagergren's pseudo-first order rate equation was used to study the specific rate constants for the adsorption of methyl orange by carbon coated monolith [15]. The graph plotted between log $\left(\mathrm{q}_{\mathrm{e}}-\mathrm{q}_{\mathrm{t}}\right)$ versus time. The pseudo-first order kinetic equation is given as Equation 3.

$$
\log \left(q_{e}-q_{t}\right)=\log q_{e}-\frac{k_{1} t}{2.303}
$$

Where $q_{e}$ is the amount of methyl orange adsorbed at equilibrium $(\mathrm{mg} / \mathrm{g}), q_{t}$ is the amount of methyl of orange adsorbed at time, $t$ $(\mathrm{mg} / \mathrm{g})$ and $k_{1}$ is therate constant of pseudo-first order adsorption ( $\mathrm{g} / \mathrm{mg} \mathrm{min}$ )

Mckay's pseudo-second order rate equation was used to study the specific rate constants for the adsorption of methyl orange by carbon coated monolith [16]. The graph was plotted between $t / q_{t}$ against time as shown in Figure 1. The pseudo-second order kinetic equation is described as Equation 4.

$$
\frac{t}{q_{t}}=\frac{1}{k_{2} q_{e}^{2}}+\frac{t}{q_{e}}
$$

Where $q_{e}$ is the amount of methyl orange adsorbed at equilibrium $(\mathrm{mg} / \mathrm{g}), q_{t}$ is the amount of methyl of orange adsorbed at time, $\mathrm{t}$ $(\mathrm{mg} / \mathrm{g})$ and $k_{2}$ is the rate constant of pseudofirst order adsorption ( $\mathrm{g} / \mathrm{mg} \mathrm{min})$.

The adsorption kinetic plots shown in Figure 2 and Figure 3 present the plots for Lagergrenfirst-order and pseudo-second-order kinetics models, respectively. The parameters obtained for two models are presented in Table 1. As shown in Figure, at initial of adsorption for first few minutes the kinetics data at various initial MO concentrations was slightly fitted in pseudofirst order kinetics. However, as the time increase, the data started to deviate. This 
explains that the adsorption only follows pseudofirst order kinetics model in the region of rapid adsorption and not at slower adsorption. This is because as the adsorption slows down, deviation starts to occur [17].

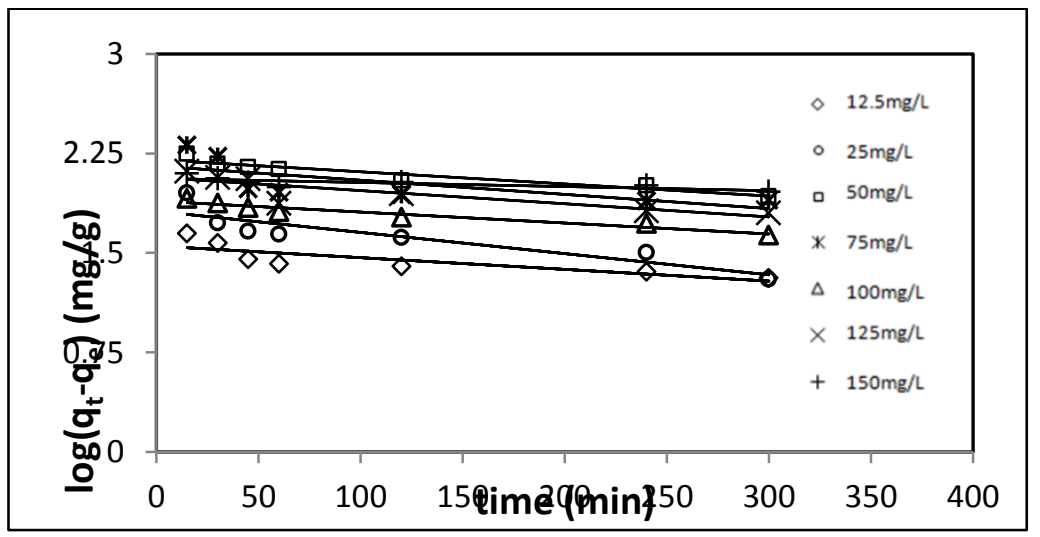

Figure 2. Pseudo-first order model for the adsorption of methyl orange by carbon coated monolith

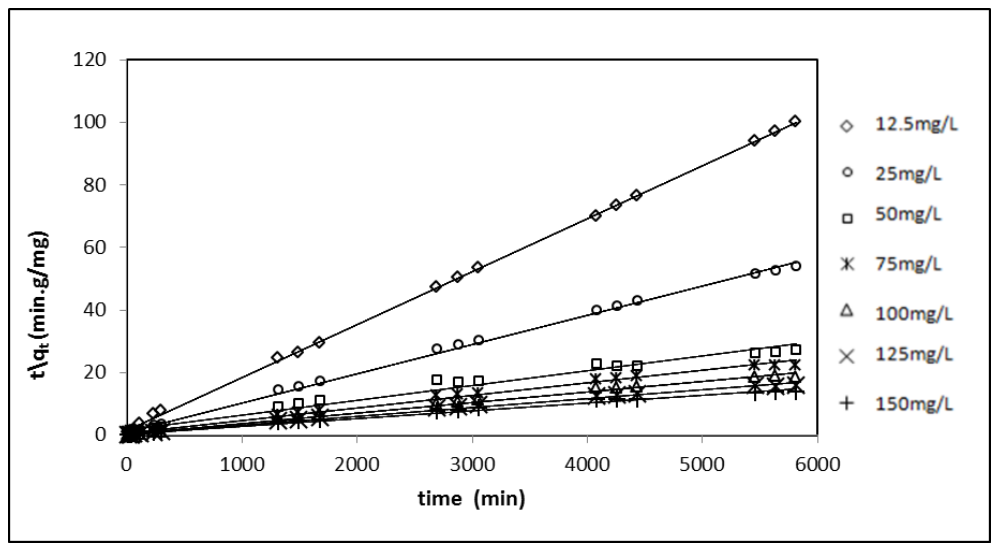

Figure 3. Pseudo-second order model for the adsorption of methyl orange on carbon coated monolith

Compared to Lagergren's pseudo-firstorder model, the pseudo-second-order model gives a straight line at various initial MO concentrations over the entire adsorption period (Figure 3) leading to higher values of $\mathrm{R}^{2}$ for pseudosecond-order model. This suggests better fitting of pseudo-second-order model. Besides this, the experimental adsorption capacity, $\mathrm{q}_{\mathrm{e}}$ (exp) values for the adsorption of MO on CCM at various concentrations were very nearer to calculated adsorption capacity, $\mathrm{q}_{\mathrm{e} \text { (cal) }}$ values indicating that adsorption system obeys the pseudo-secondorder kinetics model and thus supports the assumption behind the model that the adsorption is due to chemisorption. The values of rate constant $\mathrm{K}_{2}$ decreased from $1.89 \times 10^{-4}$ to $1.75 \times$ $10^{-5} \mathrm{~g} / \mathrm{mg}$ min with increase in initial $\mathrm{MO}$ concentrations from $12.5 \mathrm{mg} / \mathrm{L}$ to $150 \mathrm{mg} / \mathrm{L}$ indicating slower adsorption rate at higher initial concentration. Similar results were reported for the adsorption MO onto various adsorbents [1820]. While the initial adsorption rate (h) increases with increase in MO concentrations (Table 1).

From Table 1, it was found that the values of correlation coefficient, $\mathrm{R}^{2}$ of pseudo-first order kinetic model for each concentration were low and far from unity compared to $\mathrm{R}^{2}$ values for pseudo-second order kinetic model which were higher and close to unity. Higher values of $\mathrm{R}^{2}$ indicate that the adsorption follows the pseudosecond kinetic model. Furthermore, the calculated values, $\mathrm{q}_{\mathrm{e}(\mathrm{cal})}$ of pseudo-first order kinetic model were far from the experimental values, $\mathrm{q}_{\mathrm{e}(\exp )}$ at different initial concentration of methyl orange dye compared to pseudo-second order kinetic model. 
Table 1. Adsorption kinetics (pseudo-first order and pseudo-second order models) parameters of methyl orange on carbon coated monolith $\left(\mathrm{T}=20^{\circ} \mathrm{C}\right.$, stirring rate $\left.=220 \mathrm{rpm}, \mathrm{pH}=5\right)$

\begin{tabular}{|c|c|c|c|c|c|c|c|c|}
\hline & First -0 & ler-model & & & Second & rder-mod & & \\
\hline $\mathrm{C}_{0}(\mathrm{mg} / \mathrm{L})$ & $\overline{\mathbf{R}^{2}}$ & $\begin{array}{l}q_{\mathrm{e}, \text { cal1 }} \\
(\mathrm{mg} / \mathrm{g})\end{array}$ & $\begin{array}{l}q_{\exp } \\
(\mathrm{mg} / \mathrm{g})\end{array}$ & $\begin{array}{l}\mathbf{K}_{1} \\
\left(\min ^{-1}\right)\end{array}$ & $\mathbf{R}^{2}$ & $\begin{array}{l}\mathrm{q}_{\mathrm{e}, \mathrm{cal} 2} \\
(\mathrm{mg} / \mathrm{g})\end{array}$ & $\begin{array}{l}q_{\exp } \\
(\mathrm{mg} / \mathrm{g})\end{array}$ & $\begin{array}{l}\mathbf{K}_{2} \\
(\mathrm{~g} / \mathrm{mg} . \mathrm{min})\end{array}$ \\
\hline 12.5 & 0.6827 & 35.793 & 58.077 & 0.002073 & 0.9997 & 59.172 & 58.077 & 0.000189 \\
\hline 25 & 0.8031 & 65.118 & 108.234 & 0.003685 & 0.9985 & 107.527 & 108.234 & 8.47E-05 \\
\hline 50 & 0.9053 & 159.845 & 213.605 & 0.002073 & 0.9783 & 212.766 & 213.605 & $1.44 \mathrm{E}-05$ \\
\hline 75 & 0.4945 & 142.266 & 261.252 & 0.002533 & 0.9921 & 250.000 & 261.252 & $2.39 \mathrm{E}-05$ \\
\hline 100 & 0.9317 & 77.696 & 313.371 & 0.001842 & 0.9942 & 294.118 & 313.371 & $3.26 \mathrm{E}-05$ \\
\hline 125 & 0.7475 & 117.112 & 369.342 & 0.002303 & 0.9938 & 357.143 & 369.342 & $2.29 \mathrm{E}-05$ \\
\hline 150 & 0.5947 & 116.198 & 418.386 & 0.000691 & 0.9922 & 400.000 & 418.386 & $1.75 \mathrm{E}-05$ \\
\hline
\end{tabular}

Thus, pseudo-second order model was a better fitted than pseudo-first order model. Therefore, it can be concluded that the pseudo-second order model provided a good correlation for the adsorption of methyl orange on carbon coated monolith compared to pseudo-first order model.

In this study, the dyes adsorption kinetic data were fitted with the second-order kinetic model by non-linear regression due to its higher correlation coefficient. It indicates that adsorption kinetic process is following the pseudo-second order kinetic model. This is generally compatible with other research's result that pseudo-second order kinetic model was able to describe properly the kinetic process of dyes adsorption onto carbon coated monolith.

\section{Thermodynamic Parameters}

In order to determine the thermodynamic parameters, the experiment was carried out at different temperatures $\left(20^{\circ} \mathrm{C}, 30^{\circ} \mathrm{C}\right.$ and $\left.40^{\circ} \mathrm{C}\right)$. The thermodynamic parameters such as enthalphy $\left(\Delta H^{\circ}\right)$, entropy $\left(\Delta S^{\circ}\right)$ and free energy $\left(\Delta G^{\circ}\right)$ were determined using Equation 3 and Equation 4.

$$
\begin{aligned}
& \Delta G^{\circ}=-R T \ln K_{L} \quad(3) \\
& \Delta G^{\circ}=\Delta H^{\circ}-T \Delta S^{\circ}
\end{aligned}
$$

Where $\mathrm{R}(8.314 \mathrm{~J} / \mathrm{mol} \mathrm{K})$ is the universal gas constant, $\mathrm{T}(\mathrm{K})$ is the absolute solution temperature and $K_{L}(\mathrm{~L} / \mathrm{mol})$ is the Langmuir adsorption constant. The value of $\Delta H^{\circ}$ and $\Delta S^{\circ}$ were calculated from the slope and intercept of Van't Hoff plots of $\ln K_{L}$ against 1/T using Equation 5.

$$
\ln K_{L}=\frac{\Delta S}{R}-\frac{\Delta H}{R T}
$$

The plots of $\mathrm{q}_{\mathrm{e}}$ versus $\mathrm{C}_{\mathrm{e}}$ for methyl orange adsorption on carbon coated monolith at different temperatures $\left(20^{\circ} \mathrm{C}, 30^{\circ} \mathrm{C}\right.$ and $\left.40^{\circ} \mathrm{C}\right)$ can be shown in Figure 4. The Langmuir isotherm model assumes that adsorption takes place at specific homogeneous sites within the adsorbent and has been successfully applied to many sorption processes. The Langmuir isotherm constants and corresponding correlation coefficients were determined from the nonlinear plot of $\mathrm{q}_{e}$ versus $\mathrm{C}_{\mathrm{e}}$ and linear plot of $\mathrm{C}_{\mathrm{e}} / \mathrm{q}_{\mathrm{e}}$ versus $\mathrm{C}_{\mathrm{e}}$.

Figure 5 shows that the equilibrium capacity qe increased as the temperature increased. The highest equilibrium adsorption capacity is at $40^{\circ} \mathrm{C}$ with value of $452.3 \mathrm{mg} / \mathrm{g}$. Thus, it can be concluded that methyl orange adsorption is dependent on temperature. 


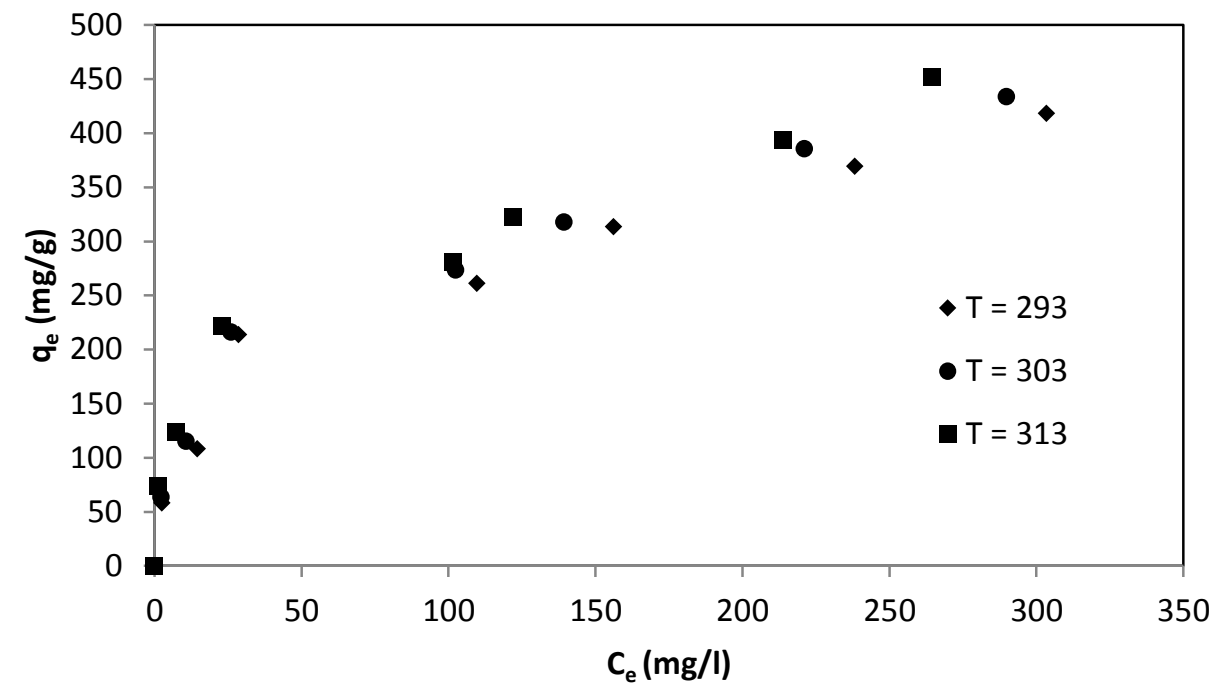

Figure 4. The nonlinear Langmuir plot of $\mathrm{q}_{\mathrm{e}}$ versus $\mathrm{C}_{\mathrm{e}}$ at different temperatures $\left(\mathrm{T}=20^{\circ} \mathrm{C}\right.$ to $40^{\circ} \mathrm{C}$, stirring rate $\left.=220 \mathrm{rpm}, \mathrm{pH}=5\right)$

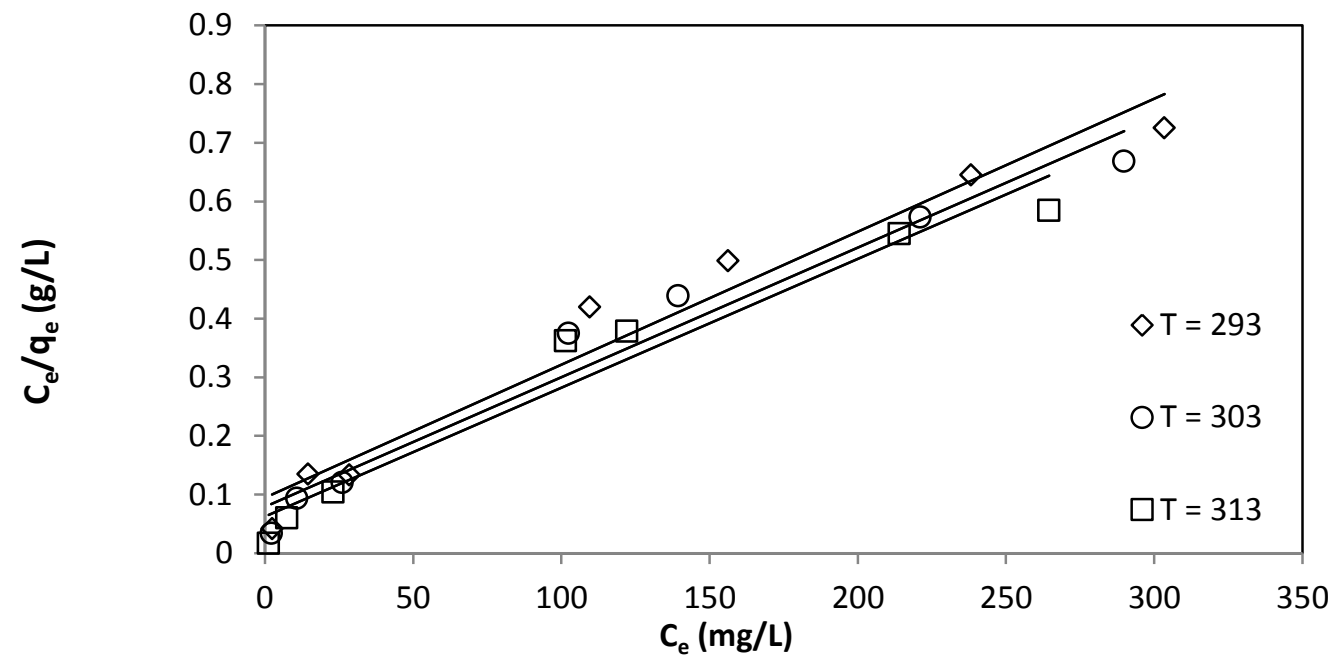

Figure 5. Langmuir isotherm plots for MO adsorption on CCM

The maximum capacity $\mathrm{q}_{\max }(454.5 \mathrm{mg} / \mathrm{g})$ determined from the Langmuir isotherm defines the total capacity of the carbon coated monolith for methyl orange dye. This shows that the higher the temperature the higher the adsorption capacity.

In addition, the effect of isotherm shape can be used to predict whether an adsorption system is favorable or unfavorable in batch processes. The essential characteristics of the Langmuir isotherm can be expressed in terms of dimensionless constant separation factor or equilibrium parameter, $\mathrm{R}_{\mathrm{L}}$. The calculated $\mathrm{R}_{\mathrm{L}}$ values at different initial methyl orange concentrations and temperatures are shown in Table 2.

Table 2. The calculated $R_{L}$ values at different initial MO concentrations $(12.5 \mathrm{mg} / \mathrm{L}$ to 150 $\mathrm{mg} / \mathrm{L})$ and temperatures $\left(30^{\circ} \mathrm{C}\right.$ and $\left.40{ }^{\circ} \mathrm{C}\right)$

\begin{tabular}{ccc}
\multicolumn{3}{c}{$\mathrm{T}=\mathbf{3 0}{ }^{\circ} \mathbf{C}$} \\
\hline $\mathbf{C}_{\mathbf{0}}(\mathbf{m g} / \mathbf{L})$ & $\mathbf{C}_{\mathrm{e}}(\mathbf{m g} / \mathbf{L})$ & $\mathbf{R}_{\mathrm{L}}$ \\
\hline $\mathbf{1 2 . 5}$ & 2.153 & 0.943 \\
$\mathbf{2 5}$ & 10.749 & 0.769 \\
$\mathbf{5 0}$ & 26.002 & 0.579 \\
$\mathbf{7 5}$ & 102.451 & 0.259 \\
$\mathbf{1 0 0}$ & 139.310 & 0.204 \\
$\mathbf{1 2 5}$ & 221.026 & 0.139 \\
$\mathbf{1 5 0}$ & 289.835 & 0.110 \\
\hline
\end{tabular}




\begin{tabular}{ccc}
\multicolumn{3}{c}{$=\mathbf{4 0}{ }^{\circ} \mathbf{C}$} \\
\hline $\mathbf{C}_{\mathbf{0}}(\mathbf{m g} / \mathbf{L})$ & $\mathbf{C}_{\mathrm{e}}(\mathbf{m g} / \mathbf{L})$ & $\mathbf{R}_{\mathbf{L}}$ \\
\hline $\mathbf{1 2 . 5}$ & 1.226 & 0.959 \\
$\mathbf{2 5}$ & 7.409 & 0.793 \\
$\mathbf{5 0}$ & 23.047 & 0.552 \\
$\mathbf{7 5}$ & 101.383 & 0.219 \\
$\mathbf{1 0 0}$ & 122.145 & 0.188 \\
$\mathbf{1 2 5}$ & 213.974 & 0.117 \\
$\mathbf{1 5 0}$ & 264.492 & 0.097 \\
\hline
\end{tabular}

The fact that the value of $R_{L}$ was maintained within the range of 0 to 1 at all initial concentrations and temperatures confirmed the favorable uptake of the methyl orange by carbon coated monolith. Furthermore, free energy change, entropy change, and enthalpy change thermodynamic properties of the adsorption system were determined. The change in free energy varies considerably with temperature and is related to the equilibrium constant by the Van't Hoff equation as shown in Figure 6.
The temperature range used in this study was from $20^{\circ} \mathrm{C}$ to $40^{\circ} \mathrm{C}$. The calculated thermodynamic parameters and Langmuir constant for the methyl orange adsorption on carbon coated monolith were listed in Table 3.

The negative value of $\Delta \mathrm{G}^{\circ}$ indicates the feasibility of the process and indicates the spontaneous nature of the adsorption. The negative value of $\Delta \mathrm{G}^{\circ}$ also shows that the adsorption is highly favourable for methyl orange. The $\Delta \mathrm{G}^{\circ}$ value is more negative with decreasing temperature, which suggests that lower temperature makes the adsorption easier. The positive values of $\Delta \mathrm{S}^{\circ}$ show increased disorder and randomness at the solid solution interface of the adsorbent. The positive value of $\Delta \mathrm{S}^{\circ}$ suggests that the process is enthalpy-driven and reflects the affinity of the adsorbent for methyl orange and confirms the decreased randomness at the solid-solution interface during adsorption. The positive values of $\Delta \mathrm{H}^{\circ}$ show the endothermic nature of adsorption and the possibility of physical adsorption.

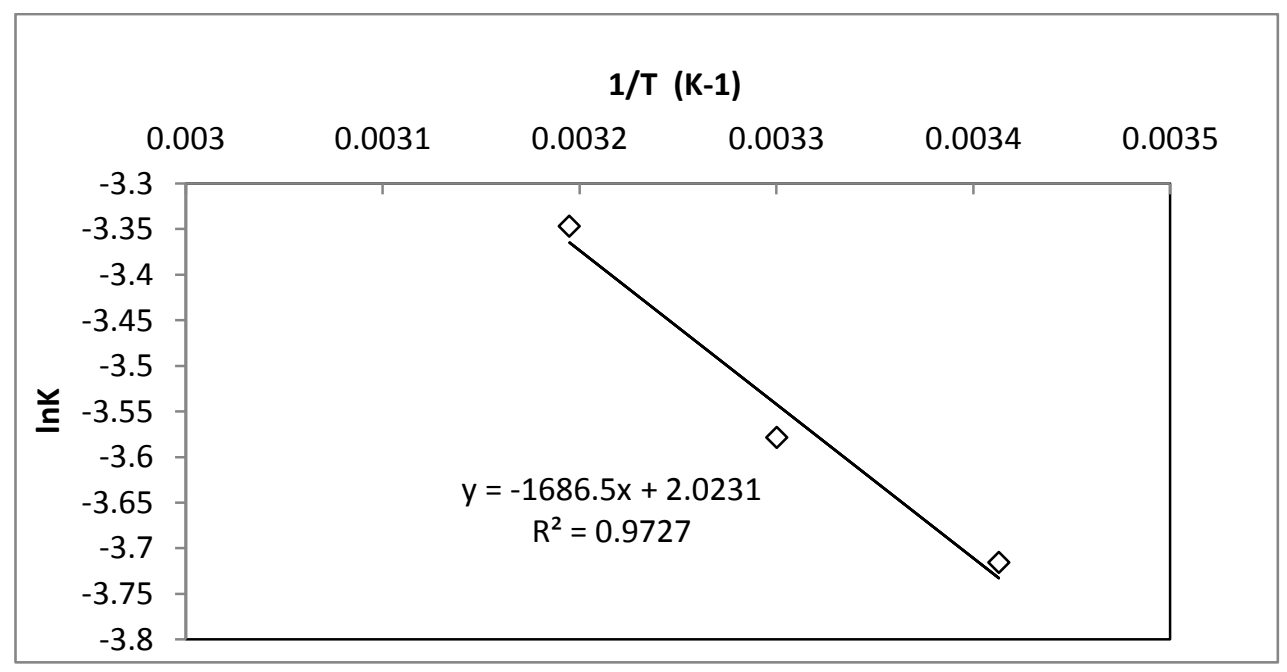

Figure 6. Van't Hoff plots of $\ln K_{L}$ against 1/T for MO adsorption on CCM

Table 3. Thermodynamic parameters for MO adsorption on CCM

\begin{tabular}{ccccc}
\hline Temperature $(\mathbf{K})$ & \multicolumn{3}{c}{$\begin{array}{l}\text { Thermodynamic parameters and } \\
\text { correlation coefficient, } \mathbf{R}^{\mathbf{2}}\end{array}$} \\
\hline & $\Delta \mathbf{G}$ & $\Delta \mathbf{H}$ & $\Delta \mathbf{S}$ & $\mathbf{R}^{\mathbf{2}}$ \\
$\mathbf{2 9 3}$ & $(\mathbf{k J} / \mathbf{m o l})$ & $(\mathbf{k J} / \mathbf{m o l})$ & $(\mathbf{J} / \mathbf{m o l} \mathbf{K})$ & 0.9727 \\
$\mathbf{3 0 3}$ & -9.0523 & 14.216 & 18.1062 & \\
$\mathbf{3 1 3}$ & -8.4316 & & & \\
\hline
\end{tabular}




\section{CONCLUSION}

The mesoporous carbon coated monoliths were characterized using BET, $\mathrm{pH}$ point zero charge and surface chemistry. The adsorption kinetics of methyl orange onto carbon coated monolith was examined in this study and fitted well with pseudo-second order kinetics with correlation good coefficient, $\mathrm{R}^{2}$ value. Thermodynamic study showed that the adsorption was a spontaneous and endothermic process. These results were concluded by the value of enthalpy change $\Delta \mathrm{H}^{\circ}$, entropy change $\Delta \mathrm{S}^{\circ}$ and free energy change, $\Delta \mathrm{G}^{\circ}$.

\section{REFERENCES}

1. Sapari N. (1996). Treatment and reuse of textile wastewater by overland flow. Desalination, 106, 179-182.

2. Lin, S.H., \& Peng, C.F. (1996). Continous treatment of textile wastewater by combined coagulation, electrochemical oxidation and activated sludge. Water Research, 30, 587-592.

3. Anjaneyulu, Y., Sureshbabu, S., Jayakumar, I, Laskhminarayana, S. \& Rao, T.H. (2005). Design and development of polymer coated piezoelectric crystal based analyzer for direct monitoring of sulphur dioxide. Journal of Scientific \& Industrial Research, 64, 426-434.

4. Mittal, A., Malviya, A., Kaur, D., Mittal, J. \& Kurup, L. (2007). Studies on the adsorption kinetics and isotherms for the removal and recovery of methyl orange from wastewaters using waste materials. Journal of Hazardous Materials, 148, 229-240.

5. Reddy, S.S., Kotaiah, B., Reddy, N.S.P., \& Velu, M. (2006). The removal of composite reactive dye from dyeing unit effluent using sewage sludge derived activated carbon. Journal of Engineering Environmental Science, 30, 367-373.

6. Hameed, B.H., Din, A.T.M., \& Ahmad, A.L. (2007). Adsorption of methylene blue onto bamboo-based activated carbon: kinetics and equilibrium studies. Journal of Hazardous Materials, 141, 819-825.

7. Kumar, A., Kumar, S., Kumar, S., Gupta, D. V. (2007). Adsorption of phenol and 4- nitro phenol on granular activated carbon in basal salt medium: Equilibrium and kinetics. Journal of Hazardous Materials, 147, 155-166.

8. Hamdaoui, O. (2006). Dynamic Sorption of methylene blue by cedar sawdust and crushed brick in fixed bed columns. Journal of Hazardous Material, B138, 293-303.

9. Tsai, W.T., Chang, C.Y., Lin, M.C., Chien, S.F., Sun, H.F., \& Hsieh, M.F. (2001). Adsorption of acid dye onto activated carbons prepared from agricultural waste bagasse by $\mathrm{ZnCl}_{2}$ activation. Chemosphere, 45, 51-58.

10. Walker, G.A. and Weatherley, L.R. (2001). Adsorption of acid dyes from aqueous solution -the effect of adsorbent pore size distribution and dye aggregation. Chemical Engineering Journal, 83 (3), 201-206.

11. Tang, Z., Song, Y., Tian, Y., Liu, L., \& Guo, Q. (2008). Effect of surfactant on the pore structure of mesoporous carbon. Microporous and Mesoporous Materials, 111, 48-54.

12. Vergunst, T., Kapteijn, F. and Moulijn, J.A. (1998). Carbon coating of ceramic monolithic substrates (preparation of catalysts vii), in: Studies Surface Science Catalysis, Elsevier Science, Amsterdam, Volume 118, pp. 175-183.

13. Lataye, D.H., Mishra, I.M. and Mall, I.D. (2006). Removal of pyridine from aqueous solution by adsorption on bagasse fly ash. Industrial and Engineering Chemistry Research,. 45, 3934-3943.

14. Goertzen, S.L., Theriault, K.D., Oickle, A.M., Tarasuk, A.C. and Andreas, H.A. (2010). Standardization of the Boehm titration. Part I. $\mathrm{CO}_{2}$ expulsion and 
endpoint determination. Carbon , 48, 1252-1261.

15. Lagergren, S. (1898). About the theory of so called adsorption of soluble substances, Kungliga Svenska Vetenskapsakademiens, Handlingar Band, 24, 1-39.

16. Ho, Y.S., Ng, J.C.Y. and Mckay, G. (2000). Kinetics of pollutants sorption by biosorbents: review. Separation and Purification Methods, 29, 189-232.

17. Crini, G., Peindy, H.N., Gilbert, F. and Robert, C. (2007). Removal of C.I. basic green 4 (malachite green) from aqueous solutions by adsorption using cyclodextrin-based adsorbent: kinetic and equilibrium studies. Separation and Purification Technology, 53, 97-110.

18. Chen, S., Zhang, J., Zhang, C., Yue, Q., Li, Y. and Li, C. (2010). Equilibrium and kinetic studies of methyl orange and methyl violet adsorption on activated carbon derived from Phragmites austries, Desalination, 252, 149-156.

19. Liu, Z., Zhou, A., Wang, G. and Zhao, X. (2009). Adsorption behavior of methyl orange onto modified ultrafine coal powder. Chinese Journal of Chemical Engineering, 17 (6), 942948.

20. Jalil, A.A., Triwahyonob, S., Adama, S.H., Rahima, N.D., Aziza, M.A., Hairom, N.H., Razalia, N.A.M., Abidina, M.A.Z. and Mohamadiah, M.Kh.A. (2010). Adsorption of methyl orange from aqueous solution onto calcined Lapindo volcanic mud. Journal of Hazardous Materials, 181, 755-762. 